\title{
Physico-chemical characterization of water and metallic contamination of Mytilus galloprovincialis in the coastal zone of Saidia
}

\author{
Khaoula Kasmi $^{1}$, Kamal Belhaj ${ }^{1}$, and Abdelhafid Chafi ${ }^{1}$ \\ ${ }^{1}$ Laboratory of Agricultural Production Improvement, Biotechnology and Environment, Faculty of Sciences, University Mohammed \\ First, 717, 60000 Oujda, Morocco.
}

\begin{abstract}
Water is a vital natural resource for life. The metal pollution of aquatic ecosystems is increasing due to the effects of urbanization and industrialization. As a result, heavy metals contamination has become a serious threat to public health because of their toxicity, long persistence, bioaccumulation, and biomagnification in the food chain. This investigation aims to evaluate seawater's Physico-chemical quality and assess the contamination risks of Mytilus galloprovincialis mussels by Cadmium, Zinc, Iron, and Copper. The study was carried out in three stations of Saidia coast during July 2019. The seawater was analyzed for its Physico-chemical parameters, and ICP-AES determined the heavy metals content in mussels. The results show that the tested water has a $\mathrm{pH}$ value ranging between 7.48-7.62 with nitrate and nitrite content range between $0-4.78 \mathrm{mg} / \mathrm{L}, 0.007-0.181 \mathrm{mg} / \mathrm{L}$, respectively. The recorded water conductivity and oxydability values ranged from 22 to $55 \mathrm{mS} / \mathrm{cm}$ and from 5.67 to $10.47 \mathrm{mg} / \mathrm{L}$. The mean concentration found in the mussels were in decreasing order, Iron $(13.5 \mathrm{mg} / \mathrm{kg})$, Zinc $(2.3 \mathrm{mg} / \mathrm{kg})$, Copper $(0.65 \mathrm{mg} / \mathrm{kg})$ and Cadmium $(0.02 \mathrm{mg} / \mathrm{kg})$, respectively. The obtained results indicate that all values are below the threshold recommended by Food and agriculture organization and world health organization.
\end{abstract}

\section{Introduction}

Marine pollution is one of today's most current concerns. The metal pollution of aquatic ecosystems is increasing due to urbanization and industrialization (anthropogenic activities). The sources of pollution in the marine environment include the paint on ships, diverse industrial processes, and agricultural chemical products. Land undergoes high development pressure; consequently, a large contaminant load enters the water system and causes water quality degradation. As a result, and over time, the contamination by heavy metals occurs, it is recalled that these latter are hazardous contaminants and consist a real threat to public health because of their toxicity, long persistence, bioaccumulation, and biomagnification in the food chain and the various segments of the environment such as water sediments and biota. Fish is a highly appreciated food and is consumed all over the world for its nutritional value. This species is known for its nutritional and therapeutic benefits. In addition to its essential high-protein quality, fish typically have rich contents of oligo-element, vitamins, and long-chain fatty acids n-3; Globally, fish accounts for about 17 percent of animal protein intake and almost $6 \%$ of proteins consumed by human beings (Jose et al., 2007).

However, fish could become a veritable threat to human health because of the heavy metals' accumulation via marine water. The fish in the aquatic system has several assimilation methods, including organ bioaccumulation (liver, heart, and kidney, etc.), ion exchange, and tissue absorption. This investigation aimed to evaluate seawater's Physico-chemical quality and assess the contamination risks of Mytilus galloprovincialis mussels by Cadmium, Zinc, Iron, and Copper.

\section{Material and methods}

The study was carried out in the summer season. Water samples were taken from three stations (S): S1: Saidia coast at the Algerian-Moroccan border near Oued kiss; S2: Saidia coastal zone; S3: near the mouth of the Moulouya. On the other hand, the Mytilus galloprovincialis mussel samples were only taken from $\mathrm{S} 1$ since they are absent in the two others (absence of rocks) (Fig. 1).

The Physico-chemical analyses of water were carried out at the Oriental Center for Water Sciences and Technologies (COSTE). The analyzed parameters were the $\mathrm{pH}$, oxidability, electrical conductivity, nitrites, and nitrates concentrations. The samples of Mytilus gallonprovincialis were cleaned by removing algae and debris using distilled water and were shelled for subsequent analyses. One gram of dried mussel was used for the elements metals analysis. The samples' mineralization was carried out by adding concentrated nitric acid ( $1 \mathrm{ml} / 100 \mathrm{mg}$ of dried matter).

\footnotetext{
*Corresponding author: kasmikhaoula77@gmail.com
} 


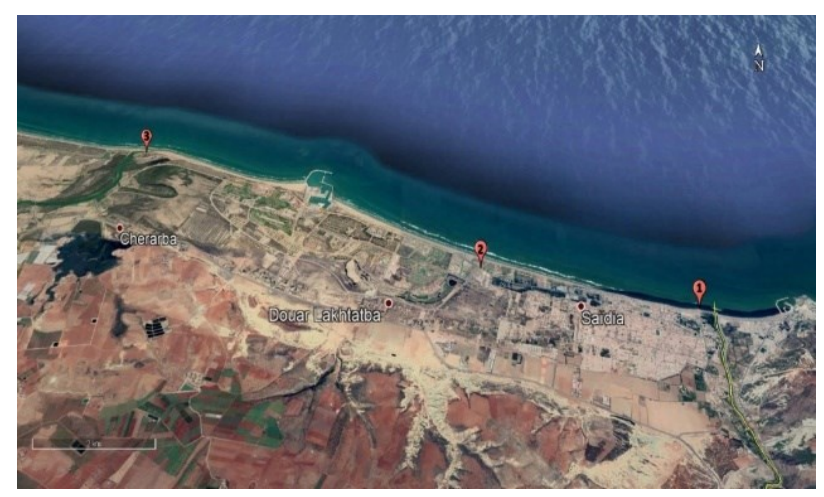

Fig 1. The sampling stations area

\section{Results and discussion}

The results of the Physico-chemical analysis of studied seawater are presented in table 1 . The $\mathrm{pH}$ values of the seawater measured in different stations 1, 2, and 3 are between 7.62 and 7.48. These values are lower than the $\mathrm{pH}$ values of Mediterranean seawater $(8,074 \pm 0,034)[1]$. This result could be explained by the geochemistry of the area while suspecting the existence of agro-industrialist effluents on both sides of the Moulouya and the Kiss wadi. In addition to the tributaries discharged into the Moulouya carrying a significant amount of organic material, which, while degrading, generates substances in its acidogenic phase that causes the $\mathrm{pH}$ decrease of the seawater. Similar results were obtained by Hassoun [1]. Karol, Bernd [2] reported that organic waste causes a decrease in the $\mathrm{pH}$ of seawater by the formation of bases via the release of protons.

Table 1. Physicochemical analysis of Mediterranean seawater from the three studied stations

\begin{tabular}{|c|c|c|c|}
\hline Parameters & Station 1 & Station 2 & Station 3 \\
\hline $\mathrm{pH}$ & $7.62 \pm 0.03$ & $7.47 \pm 0.01$ & $7.48 \pm 0.15$ \\
\hline $\begin{array}{c}\text { Oxydability } \\
\left.\text { (mg O }_{2} \mathrm{~L}^{-1}\right)\end{array}$ & $5.62 \pm 1.01^{\mathrm{a}}$ & $9.3 \pm 2.13^{\mathrm{b}}$ & $10.47 \pm 2.74^{\mathrm{c}}$ \\
\hline $\begin{array}{c}\text { Conductivity } \\
(\mathrm{mS} / \mathrm{cm})\end{array}$ & $55 \pm 10.13^{\mathrm{a}}$ & $55 \pm 8.9^{\mathrm{a}}$ & $22 \pm 3.6^{\mathrm{b}}$ \\
\hline $\begin{array}{c}\text { Nitrate } \\
(\mathrm{mg} / \mathrm{L})\end{array}$ & $\mathrm{ND}$ & $0.87^{\mathrm{b}}$ & $4.78^{\mathrm{c}}$ \\
\hline $\begin{array}{c}\text { Nitrite } \\
(\mathrm{mg} / \mathrm{L})\end{array}$ & $0.007 \pm 0.00^{\mathrm{a}}$ & $0.013 \pm 0.00^{\mathrm{b}}$ & $0.181 \pm 0.00^{\mathrm{b}}$ \\
\hline
\end{tabular}

Values with different letters are significantly $(p<0.05)$ different within rows; ND: not detected

Table 2. Trace element content in Mytilus gallonprovincialis mussels from Station 1

\begin{tabular}{|c|c|c|}
\hline $\begin{array}{c}\text { Trace element } \\
(\mathbf{m g} / \mathbf{k g})\end{array}$ & Mean $\pm \mathbf{S D}$ & $\begin{array}{c}\text { Standard } \\
(\mathbf{m g} / \mathbf{k g})\end{array}$ \\
\hline Cadmium & $0.02 \pm \mathbf{0 . 0 0}$ & 1 \\
\hline Copper & $0.65 \pm \mathbf{0 . 0 0}$ & $50-150$ \\
\hline Zinc & $2.3 \pm \mathbf{0 . 1 7}$ & $200-500$ \\
\hline Iron & $13.5 \pm \mathbf{1 . 4 3}$ & $100-150$ \\
\hline
\end{tabular}

\subsection{The nitrite and nitrate content:}

The values found for nitrates range between $0 \mathrm{mg} / \mathrm{L}$ and $4.78 \mathrm{mg} / \mathrm{L}$, respectively, for S1 and S3. As for the nitrites' values range between $0.007 \mathrm{mg} / \mathrm{L}$ and $0.18 \mathrm{mg} / \mathrm{L}$, respectively, for $\mathrm{S} 1$ and $\mathrm{S} 3$ (Table 1). The nitrite values recorded are low due to its oxidation to nitrate via the phytoplankton or by photo-reduction.

The increase in nitrate concentration in the third station located at the mouth of the Moulouya could be due to the contributions received by Oued Moulouya, which is experiencing severe degradation, especially in agricultural activity in the region. In addition, the intensive use of nitrogenous fertilizers and irrigation techniques pollute the waters of Moulouya. This water's flow loaded with nitrate towards the sea could cause this increase in nitrate at the third station.

\subsection{Variation in Oxidability}

The obtained oxidability values range between $5,62 \mathrm{mg}$ of O2/L and 10,47 $\mathrm{mg}$ of O2/L, respectively, for S1 and S3 (Table 1). The stations' oxidability values show that the further we go towards Moulouya, the more the value of the oxidability increases; That is to say, the load of oxidizable matter increases in the middle. The oxidability recorded at the second station is very close to the third; this is explained by the short distance between the two stations.

Therefore, we could assume that the origin of the oxidizable matter present in the zone is the contributions coming from Moulouya. This river knows a substantial degradation due to agricultural activities on the level of the Triffa plain, as well as domestic and industrial plants in the towns of Missour, Outat El-Haj, Tindit, Guercif, and Taourirt, which liquid discharges directly without prior treatment, which influences the entire watershed of the Moulouya [3].

\subsection{The variation of electrical conductivity}

The recorded values for EC range between $55 \mathrm{mS} / \mathrm{cm}$ for both S1 and S2 and $22 \mathrm{mS} / \mathrm{cm}$ for S3 (Table 1). From the results, we notice that the conductivity of the two stations $\mathrm{S} 1$ and $\mathrm{S} 2$ is in the norm, which is $56 \mathrm{mS} / \mathrm{cm}$. The increase in the conductivity of a solution is due to the intense concentration of salts such as chlorides [1]. On the other hand, the value recorded in S3 is lower than the norm (22 $\mathrm{mS} / \mathrm{cm}$ ). This decrease would be due to the dilution of the resort's waters by the fresh waters of Moulouya. Large inflows of fresh water, resulting in a decrease in the mean salinity of the water [4]. Agricultural activity in the Triffa plain would probably have contributed to the decrease in the conductivity of the water from the third station.

The influence of agricultural activities on many Mediterranean wetlands has often disrupted their functioning. Tamisier and Grillas [4] have reported that many temporary systems have been converted to permanent systems, and salinity has decreased due to agricultural production flows, which often dominate diets of salinity. 


\subsection{Heavy metals}

The results of the heavy metals concentrations $(\mathrm{Cd}, \mathrm{Cu}$, $\mathrm{Zn}$, and $\mathrm{Fe}$ ) in the Mussels collected from the Saidia coastal zone are given in Table 2. The mean concentration in the mussel is the following sequence $\mathrm{Fe}>\mathrm{Zn}>\mathrm{Cu}>$ $\mathrm{Cd}$ during summer. The copper content found in mussels is around $0.65 \mathrm{mg} / \mathrm{kg}$. This value is very far from the limits set by the FAO ( 50 to $150 \mathrm{mg} / \mathrm{kg}$ ); Likewise, if we compare it with the limit value determined by Nauen [5], which is $30 \mu \mathrm{g} / \mathrm{g}$. However, our result is in agreement with those reported by Schintu, Durante [6] which (5-13 $\mathrm{mg} / \mathrm{kg}$ ) and remain lower than those reported in the literature for other species of mollusks bivalves: $38 \mathrm{mg} / \mathrm{kg}$ for Chamelea.gallina [7] and $175 \mathrm{mg} / \mathrm{kg}$ for the species Donax.trunculus. The Cd content in mussels is in the order of $0.02 \mathrm{mg} / \mathrm{kg}$ dry matter. This registered value is lower than the European Community permissible level of $\mathrm{Cd}$ for human consumption $(1 \mathrm{mg} / \mathrm{kg}$ wet weight). In addition, our result is below the limit fixed by the Economic Commission for Europe of the order of $1 \mathrm{mg}$ $/ \mathrm{kg}$. Zinc appears to have a protective effect against the toxicities of cadmium and lead. However, in excess quantities, essential elements can also be toxic and cause serious health threats to human. The recorded value is of $2.3 \mathrm{mg} / \mathrm{kg}$ and is considerably lower than the limits set by FAO (200 to $500 \mathrm{mg} / \mathrm{kg})$. Concerning the iron content in the sample of mussels taken is of the order of $13.5 \mathrm{mg} / \mathrm{kg}$. The Fe content is lower than those found in the literature for the same species of the order of $2462 \mathrm{mg} / \mathrm{kg}$ [8] and other species of bivalves such as Scrabicularia.plana $(1657-3-4452 \mathrm{mg} / \mathrm{kg})$ [9], Cardium.edule (950-1026 $\mathrm{mg} / \mathrm{kg})$ [10] and Mytilus edulis $(1380 \mathrm{mg} / \mathrm{kg})$ [11].

\section{Conclusion}

Physico-chemical characterization of water and metallic contamination of Mytilus galloprovincialis in the coastal zone of Saidia has been studied. The assessment of the seawater physicochemical parameters at the level of the Saidia coastal zone allowed us to deduce the negative effect of agricultural intensification in the Triffa plain on seawater quality. However, the result of heavy metal content shows that all the recorded values are acceptable. Further investigations are needed to study the Ecotoxicological risks of Saidia coastal to determine the different pollutants and their origins to establish corrective measures for sustainable development.

\section{References}

1. A.E.R. Hassoun, Analyse et Modélisation de l'Acidification en Mer Méditerranée, in Énergie et Environnement "Institut de Modélisation et d'Analyses en GéoEnvironnement et Santé". 2014, Université de perpignan via domitia: Perpignan. p. 216.

2. K. Karol, S. Bernd, H. Karoline, U. Machulik, and D. Schulz-Bull, Journal of Marine Systems, 132 106115 (2014)
3. M. Makhoukh, M. Sbaa, A. Berrahou, and M. Van Clooster, LARHYSS Journal P-ISSN 1112-3680/EISSN 2521-9782, (2011)

4. A. Tamisier and P. Grillas, Biological Conservation, 70, 39-47 (1994)

5. C.E. Nauen, FAO Fisheries Circular (FAO). no. 764., (1983)

6. M. Schintu, L. Durante, A. Maccioni, P. Meloni, S. Degetto, and A. Contu, Marine Pollution Bulletin, 57, 832-837 (2008)

7. J. Usero, J. Morillo, and I. Gracia, Chemosphere, 59, 1175-1181 (2005)

8. F. Çevik, M.Z.L. Göksu, O.B. Derici, and Ö. Fındık, Environmental monitoring and assessment, 152, 309-317 (2009)

9. Cheggour and M., Contribution à l'étude d'un milieu paralique : l'estuaire de Bou regreg (Côte atlantique marocaine) : conditions écologiques globales ; étude de la contamination métallique, in Biologie. 1998, Université Mohamed 5: Rabat. p. 337.

10. A. Kaimoussi, A. Mouzdahir, S. Bakkas, And A. Chafik, Bulletin de l'Institut Scientifique, Rabat, 1997, 95-102 (1998)

11. J. Pempkowiak, A. Sikora, and E. Biernacka, Chemosphere, 39, 313-321 (1999) 